\title{
VESICULAR-ARBUSCULAR-/ECTO-MYCORRHIZA SUCCESSION IN SEEDLINGS OF EUCALYPTUS SPP.
}

\author{
Vera Lúcia dos Santos ${ }^{1}$; Rosa Maria Muchovej²; Arnaldo Chaer Borges ${ }^{1}$; \\ Júlio César L. Neves ${ }^{3}$; Maria Catarina M. Kasuya ${ }^{1 *}$ \\ ${ }^{1}$ Departamento de Microbiologia and ${ }^{3}$ Departamento de Solos, Universidade Federal de Viçosa, Viçosa, MG, Brasil. \\ ${ }^{2}$ Forages/Sugar Cane Agronomist, University of Florida - IFAS - SWFREC.
}

Submitted: June 26, 2000; Returned to authors for corrections: February 05, 2001; Approved: May 28, 2001

\begin{abstract}
The occurrence of vesicular-arbuscular mycorrhizae (AM) and ectomycorrhizae (ECM) in the same root system was observed when species of Eucalyptus urophylla S.T. Blake, E. citriodora Hook f., E. grandis W. Hill ex Maiden, E. cloeziana F. Muell. and E. camaldulensis Dehnh were simultaneously inoculated with Glomus etunicatum Becker \& Gederman and Pisolithus tinctorius (Per.) Cocker \& Couch, isolate Pt 90A. The succession between the two fungi was observed. In general ectomycorrhizal colonization increased followed by a decrease in AM. Pisolithus tinctorius was favored in simultaneous inoculation with $G$. etunicatum, and the positive effect of the simultaneous inoculation of both fungi in the percent colonization by the AM fungus occurred up to 60 days after inoculation. After 120 days, colonization of roots by $G$. etunicatum decreased in the presence of P. tinctorius. When inoculated simultaneously, the proportion of AM and ECM varied with evaluation time, while the combined percentage of mycorrhizal roots approached the maximum and remained more or less constant after 60 days, suggesting that there could be competition between the fungi for limiting substrate. The maximum percent mycorrhizal colonization varied with Eucalyptus species and the highest value was observed for E. camaldulensis, followed in order by E. citriodora, $E$. urophylla, E. grandis and E. cloeziana.
\end{abstract}

Key words: Glomus etunicatum, Pisolithus tinctorius, succession, Eucalyptus

\section{INTRODUCTION}

Eucalyptus is a genus of commercial forest trees that presents many desirable characteristics such as rapid growth, high cellulose production and resistance to disease and adverse environmental conditions. Thus, its use in reforestation programs in the tropics has been increasing steadily. Most forest trees form only one type of mycorrhizal association, either ectomycorrhiza (ECM) or vesicular-arbuscular mycorrhiza (AM) (26). The occurrence of AM to ECM succession on plants exhibiting both types of symbioses has been suggested for some host plants, including the genus Eucalyptus $(2,3,10,19,25,29)$. The possibility of negative interactions among mycorrhizal fungi has been suggested (22).
The AM-ECM succession may be linked to spatial competition for infection sites and differential colonization rates by the two types of fungi (10). Furthermore, root colonization by mycorrhizal fungi may be inhibited by chemical compounds produced by a resident fungus or by the host, by mechanical barriers, by competition for carbohydrates, and also by the rhizosphere community $(14,20,21,31)$.

There is not very much published research on the behavior of the AM and ECM fungi when inoculated simultaneously onto Eucalyptus species. The objectives of this work were to verify the occurrence of AM and ECM fungi in the root systems of five species of Eucalyptus and to investigate the interaction between the mycorrhizal fungi inhabiting the same root system.

\footnotetext{
* Corresponding author. Mailing address: Departamento de Microbiologia, Universidade Federal de Viçosa, 36571-000 Viçosa, MG, Brasil. Fax: (+5531) 899-2573, E-mail: mkasuya@ mail.ufv.br
} 


\section{MATERIALS AND METHODS}

The experiment was carried out in a greenhouse using a 4 x $5 \mathrm{x}$ 8 factorial design, consisting of four inoculation treatments, five host species and eight harvests, with eight replicates for each harvest, totaling 1280 plants. The inoculation treatments were: (T1) AM fungus; (T2) ECM fungus; (T3) AM fungus and ECM fungus innoculated simultaneously; and (T4) a non-inoculated control. The treatments were arranged in randomized blocks. The hosts species were Eucalyptus urophylla S.T. Blake, E. citriodora Hook f., E. grandis W. Hill ex Maiden, E. cloeziana F. Muell. and E. camaldulensis Dehnh. The harvest times were 30, 45, 60, 75, 90, 120, 150 and 180 days after transplanting.

Seeds from five Eucalyptus species were surface desinfested in a $30 \%(\mathrm{v} / \mathrm{v})$ hydrogen peroxide solution for 8 minutes, washed with sterile distilled water and sown in plastic trays containing acid-washed and autoclaved quartz sand. The seedlings were watered daily. Two 35 day-old plants were transferred to each perforated black plastic bag containing $500 \mathrm{~g}$ of soil-sand mixture $(2: 1 \mathrm{w} / \mathrm{w})$. Soil was removed from the superficial layer (0 to 20 $\mathrm{cm}$ ) of an oxisol (Yellow-red Latosol) and treated with methyl bromide $\left(100 \mathrm{~cm}^{3} / \mathrm{m}^{3}\right.$ soil). Liming was added to raise the soil $\mathrm{pH}$ to 5.6 and incubated for 20-days. At that time, soil samples were removed for analysis. The soil contained $25 \mathrm{mg}$ of extractable $\mathrm{P}$ (Mehlich-1); $1.50 \mathrm{Cmol}_{\mathrm{c}}$ of $\mathrm{Ca}(1 \mathrm{M} \mathrm{KCl})$ and $0.40 \mathrm{Cmol}_{\mathrm{c}}$ of $\mathrm{Mg}$ (1M KCl) per $\mathrm{dm}^{3}$.

The AM fungus was Glomus etunicatum Becker \& Gederman. The inoculum was produced on Sorghum bicolor L. Moench plants inoculated with the fungus and grown on a soil-sand mixture $(2: 1 \mathrm{w} / \mathrm{w})$ in the greenhouse for four months. Inoculum consisted of $10 \mathrm{~g}$ of the soil-sand mixture, containing colonized root fragments, fungal hyphae and approximately 1,700 spores, per plastic bag. The inoculum was placed $5 \mathrm{~cm}$ below the substrate surface at the time of seedling introduction.

The ECM fungus was Pisolithus tinctorius (Pers.) Coker and Couch, isolate 90A. For inoculum production, eight $5.0 \mathrm{~mm}$ diam. disks containing fungal mycelium, removed from the borders of the colonies grown in $20 \mathrm{~mL}$ of modified Melin-Norkrans (MMN) agar (23), pH 5.5, during 17 days at $28^{\circ} \mathrm{C}$, were transferred to 125 $\mathrm{mL}$ Erlenmeyer flasks containing $50 \mathrm{~mL}$ of liquid MMN. Flasks were incubated at $28^{\circ} \mathrm{C}$, for 25 days in the absence of light, and were briefly shaken manually every 2 days, for aeration of the medium. The mycelium was collected, washed with sterilized distilled water and fragmented with sterile distilled water for $2 \mathrm{~s}$ in a blender $(0.334 \mathrm{~g}$ of mycelium $/ 100 \mathrm{~mL}$ water). Five $\mathrm{mL}$ of this mycelial suspension were injected around the root system of each transplanted Eucalyptus seedling. Additionally, $5 \mathrm{~mm}$ diam. disks containing mycelium removed from the edge of colonies grown in solid MNM for 21 days at $28^{\circ} \mathrm{C}$ were placed at the time of seedling transfer, close proximity to the root system, to ensure abundant viable inoculum. Non-inoculated seedlings were used as controls (treatment T4).
Plants were watered daily with distilled water, and soil moisture content was maintained near field capacity. Twenty days after transplanting, one of the seedlings was removed to produce a uniform stand, leaving only one plant per plastic bag. Fifteen days after transplanting, a second inoculation with the ectomycorrhizal fungus was done using a fresh suspension of fragmented mycelium, obtained as previously described.

A micronutrient solution providing $0.271 \mathrm{mg} \mathrm{B}\left(\mathrm{H}_{3} \mathrm{BO}_{3}\right)$; $\left.1.211 \mathrm{mg} \mathrm{Mn}\left(\mathrm{MnCl}_{2} \cdot 4 \mathrm{H}_{2} \mathrm{O}\right) ; 0.050 \mathrm{mg} \mathrm{Mo}\left[\left(\mathrm{NH}_{4}\right) 6 \mathrm{Mo}_{7} \mathrm{O}_{24} \cdot 4 \mathrm{H}_{2} \mathrm{O}\right)\right]$; $1.334 \mathrm{mg} \mathrm{Zn}\left(\mathrm{ZnCl}_{2} \cdot \mathrm{H}_{2} \mathrm{O}\right) ; 0.519 \mathrm{mg} \mathrm{Fe}\left(\mathrm{FeCl}_{3} \cdot 6 \mathrm{H}_{2} \mathrm{O}\right)$; and 0.433 $\mathrm{mg} \mathrm{Cu}\left(\mathrm{CuCl}_{2} \cdot 2 \mathrm{H}_{2} \mathrm{O}\right)$, per $\mathrm{kg}$ of soil was applied to the pots at 21 , 49, 77, 105 and 160 days after transplanting. Nitrogen $(20 \mathrm{mg} /$ $\mathrm{kg})$ and $\mathrm{S}(22.86 \mathrm{mg} / \mathrm{kg})$ were also applied as $\left(\mathrm{NH}_{4}\right)_{2} \mathrm{SO}_{4}$ at the same time.

A different block of plants was harvested at each evaluation time, when the roots were washed in running tap water and blotted with paper towels. Three samples from different root system positions were randomly collected to form a composite sample for mycorrhizal colonization assays. Roots were cut into 1 to $2 \mathrm{~cm}$ long pieces and preserved in a FAA solution $(5 \mathrm{~mL}$ of formaldehyde, $5 \mathrm{~mL}$ of acetic acid and $90 \mathrm{~mL}$ of ethyl alcohol). To assess colonization, fine roots were cleared with $10 \% \mathrm{KOH}$ and stained with $0.05 \%$ Trypan Blue (27). For more lignified segments, the technique of Koske and Gemma (18) was used. Subsequently both types of mycorrhizal were estimated by the grid-line intersect method (15). Positive counts for AM colonization included the presence of vesicles or arbuscules or typical mycelium within the roots. Roots colonized by ectomycorrhizal fungi but lacking either a Hartig net or a fully formed mantle were included with ectomycorrhizae. When observed, the dual mycorrhizae were included when calculating the percentage of root length colonized by AM, and also when calculating the percentage of root length colonized by ECM.

Statistical analysis consisted of a full analysis of variance. Percent colonization (\%) was transformed by $\operatorname{arcsine}(\% / 100)^{1 / 2} \mathrm{X}$ $(180 / \pi)$, to evaluate the effects of fungal treatments, Eucalyptus species and time of evaluation.

The influence of symbionts on the respective colonization percentages was evaluated by contrast analysis described as: $\mathrm{C} 1$ $=(\mathrm{AM}-\mathrm{T} 1) \mathrm{vs}(\mathrm{AM}-\mathrm{T} 3)$ for contrasts comparing the percentage of colonization by the AM fungus when individually inoculated versus the colonization percentage by the AM fungus in the simultaneous inoculation treatment; and as C2 $=($ ECM-T2 $)$ vs (ECM-T3) for contrasts comparing the percentage of colonization by the ectomycorrhizal fungus when individually inoculated versus the percentage of colonization by the ectomycorrhizal fungus in the simultaneous inoculation treatment.

\section{RESULTS AND DISCUSSION}

Root colonization of Eucalyptus spp. by G. etunicatum or $P$. tinctorius occurred in all seedlings treatments when inoculated 

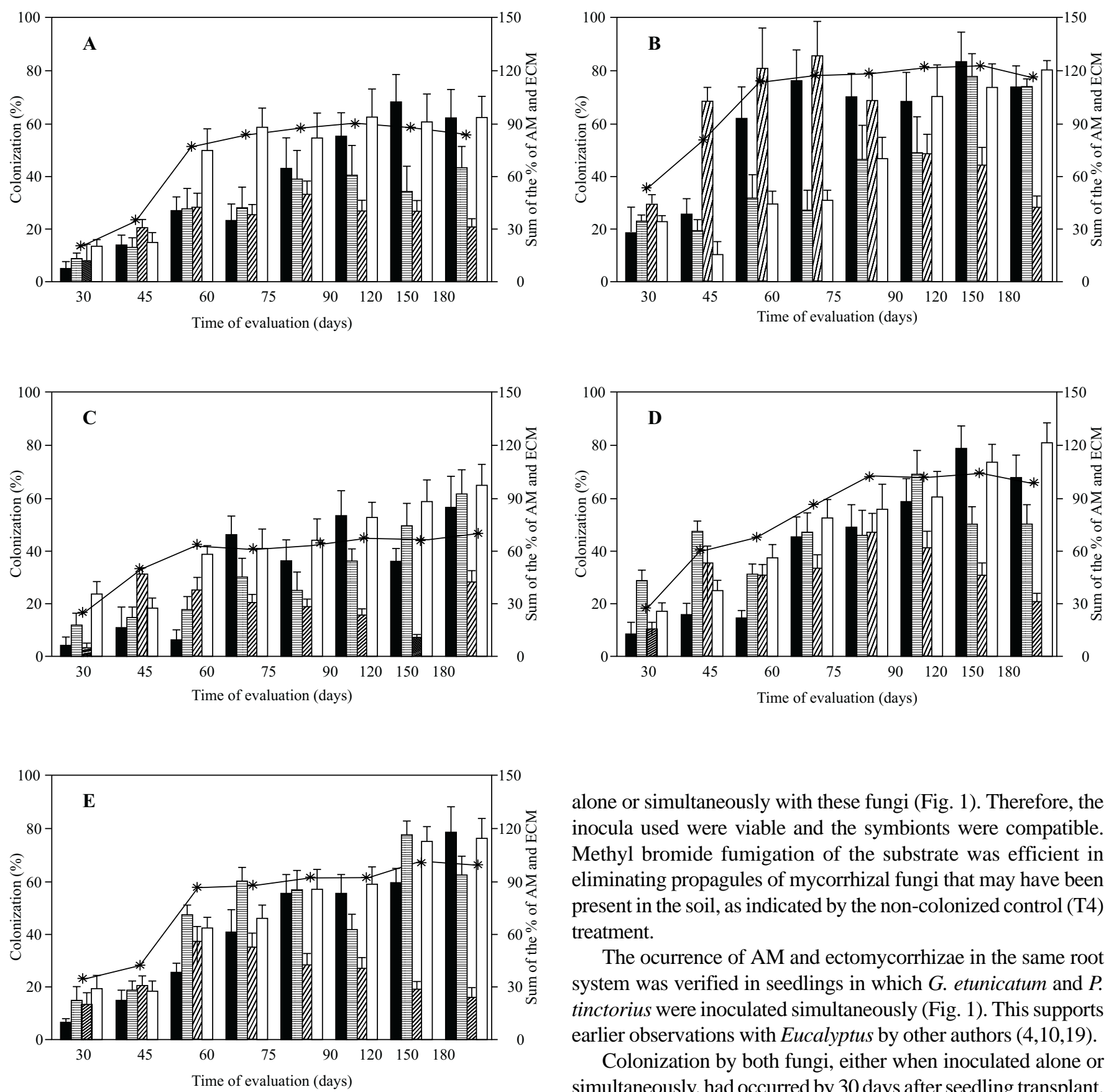

alone or simultaneously with these fungi (Fig. 1). Therefore, the inocula used were viable and the symbionts were compatible. Methyl bromide fumigation of the substrate was efficient in eliminating propagules of mycorrhizal fungi that may have been present in the soil, as indicated by the non-colonized control (T4) treatment.

The ocurrence of AM and ectomycorrhizae in the same root system was verified in seedlings in which $G$. etunicatum and $P$. tinctorius were inoculated simultaneously (Fig. 1). This supports earlier observations with Eucalyptus by other authors $(4,10,19)$.

Colonization by both fungi, either when inoculated alone or simultaneously, had occurred by 30 days after seedling transplant. When both fungi were simultaneously inoculated, the ratio between percent colonization by the AM fungus and percent colonization by the ECM fungus (AM/ECM) increased up to 45 days in all of Eucalyptus species (Fig. 2). The (AM/ECM) ratio values decreased after this period. These observations suggest a succession in this dual system, where increased colonization by ECM was accompanied by decreased AM colonization. The initial dominance of AM may be due to the faster germination and growth of the AM propagules, to the reserves available in these propagules which may support hyphal growth in the direction of 
roots, or the quantity of existent propagules. Growth of ectomycorrhizal hyphal fragments used as inoculum and the primary colonization of roots by $P$. tinctorius was slower, and yet, after a period of time, there was an increase in the rate of colonization due to secondary infections. Various authors has been emphasized the importance of secondary infections in the formation of ectomycorrhizae process $(9,10)$.

Differences observed in percent of roots colonized by both $\mathrm{AM}$ and ectomycorrhizal fungi may be due to the competition between both of them (10). These authors discuss three probable and distinctive alternatives for the two-symbiont system. First, the root colonized by the AM fungus would leave a root cap/meristem region that was not colonized and open to later colonization by the ectomycorrhizal fungus. Second, the dual mycorrhizae result from AM colonization extending internally into an ECM. The third alternative considers that when an ectomycorrhizal colonization occurs first, the mantle persists and restricts the preferential entry sites for the arbuscular fungus (young differentiated epidermal cells) preventing subsequent entrance by AM fungus $(22,24)$. Alternatively, such temporal replacements of AM by ECM might result from changes in host physiology and carbohydrate productivity with age (12).

The proportion of AM and ECM colonization varied with the time of evaluation, but the sum of the percent root colonization of AM and ECM was close to a maximum and constancy after 60 days (Fig. 1). This result suggests that there is a limitation to how much fungal biomass a Eucalyptus root system will support. It may be that there is a competition between both mycorrhizal fungi for infection sites and for carbohydrates. The higher values of these sums varied with Eucalyptus species. These sums (mean

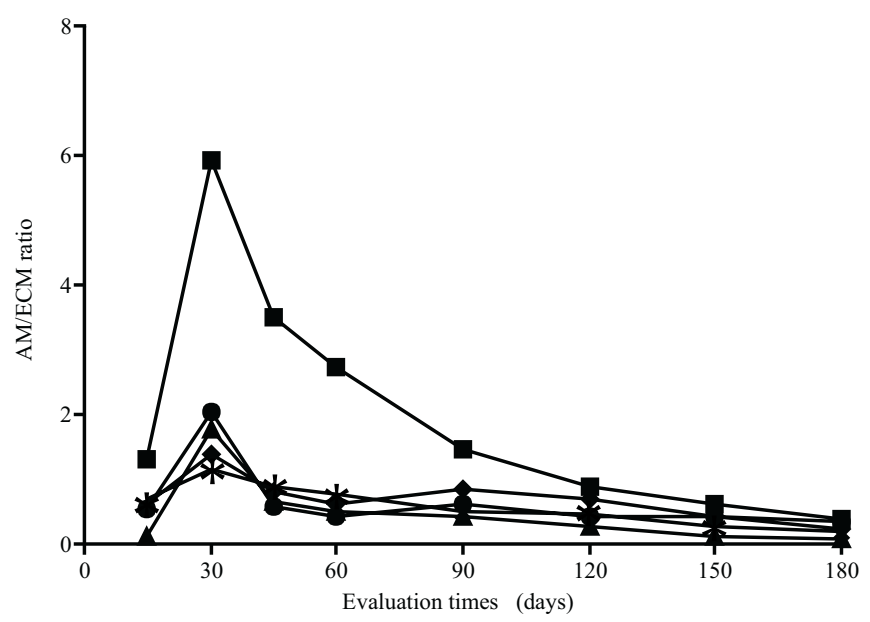

Figure 2. Ratio between percent colonization by the G. etunicatum and by P. tinctorius in roots of Eucalyptus grandis (-O-), E.

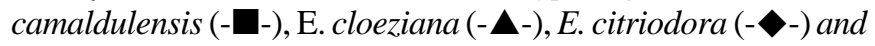
E. urophyla (-*-) in different evaluation times. over time) were 117\% for E. camaldulensis (Fig. 1B), 106.2\% for E. citriodora (Fig. 1D), 93.1\% for E. urophylla (Fig. 1E), $86.8 \%$ for E. grandis (Fig. 1A), and $63.3 \%$ for E. cloeziana (Fig. 1C). These results may be consequence of the different root dry weight, root system growth rates, and symbiont compatibility. In general, plant species differ as to the period of time needed for the establishment of mycorrhizal associations (16), and in the maximum proportion of root system that may become colonized $(5,6,17,30)$.

The established contrasts indicate that the simultaneous inoculation of $G$. etunicatum and P. tinctorius affected the colonization percentage these fungus relative to single inoculations throughout the experimental period (Table 1). The $\mathrm{C} 1$ positive values contrasts, in the three last evaluations, indicate that inoculation with G. etunicatum resulted in percent-colonized root significantly higher than those simultaneously inoculated with $P$. tinctorius. This result suggests that a negative interaction existed between the two fungi at these stages of the association. Negative interactions may occur and are characterized by the decrease in growth or reproduction of a species in the presence of another species (22). The positive effect of the simultaneous inoculation of both fungi in the percent colonization by the AM fungus ( $\mathrm{C} 1$ negative values) was verified at 45 and 60 days for $E$. camaldulensis and E. citriodora, and at 45, 60 and 75 days for E. cloeziana (Table 1).

In a number of the evaluation periods, inoculation of $P$. tinctorius simultaneously with $G$. etunicatum resulted in percent colonized root of $P$. tinctorius significantly higher than those where inoculation was done individually (Table 1). These percentages occurred at $60,75,120$ and 150 days after transplanting for E. grandis; at 45, 150 and 180 days for $E$. citriodora, and 120 days for E. camaldulensis. For E. cloeziana and E. urophylla, these trends of positive effects of the simultaneous inoculation were observed but were not significant by the $\mathrm{F}$ test $(* \mathrm{P}<0.05)$ (Table 1$)$.

Notice that there is an initial predominance of the AM fungus followed by its substitution by the ectomycorrhizal fungus as time progressed. Our data on the succession of ectomycorrhizal fungi over AM are consistent with previous reports of fungal sucession in AM/ectomycorrhizal hosts and local or short-range inhibition of colonization by AM fungi in the presence of certain ectomycorrhizal fungi $(10,13,22)$.

\section{ACKNOWLEDGEMENTS}

This study was supported in part by grants from Financiadora de Projetos (FINEP) and the Florida Agricultural Experiment Station. The authors are also grateful to CAPES and CNPq for providing a Master's Scholarship to the senior author and research fellowships to the other authors. Florida Agricultural Experiment Station Journal Series No. R-06264. 
Table 1. Contrast values for percent root colonization of Eucalyptus seedlings by Glomus etunicatum and Pisolithus tinctorius at the respective evaluation times.

\begin{tabular}{|c|c|c|c|}
\hline \multirow{2}{*}{$\begin{array}{c}\text { Species } \\
\text { E. grandis }\end{array}$} & \multirow{2}{*}{$\begin{array}{l}\begin{array}{c}\text { Evaluation } \\
\text { times (days) }\end{array} \\
30\end{array}$} & \multicolumn{2}{|c|}{$\begin{array}{c}\% \text { Colonization } \\
\mathrm{C} 1^{1} \mathrm{C} 2^{2}\end{array}$} \\
\hline & & $3.21 \mathrm{NS}$ & $5.15 \mathrm{NS}$ \\
\hline & 45 & $-6.54 \mathrm{NS}$ & $-1.97 \mathrm{NS}$ \\
\hline & 60 & $-0.78 \mathrm{NS}$ & $-22.21 *$ \\
\hline & 75 & $-2.30 \mathrm{NS}$ & $-30.48 * *$ \\
\hline & 90 & $10.36 \mathrm{NS}$ & $-15.90 \mathrm{NS}$ \\
\hline & 120 & $28.53 * *$ & $-22.32 *$ \\
\hline & 150 & $41.38 * *$ & $-26.76^{*}$ \\
\hline & 180 & $41.81 * *$ & $-19.14 \mathrm{NS}$ \\
\hline \multirow[t]{8}{*}{ E. camaldulensis } & 30 & $10.55 \mathrm{NS}$ & $0.11 \mathrm{NS}$ \\
\hline & 45 & $-42.18 * *$ & $8.76 \mathrm{NS}$ \\
\hline & 60 & $-17.93 *$ & $2.15 \mathrm{NS}$ \\
\hline & 75 & - $7.94 \mathrm{NS}$ & $-2.87 \mathrm{NS}$ \\
\hline & 90 & $2.06 \mathrm{NS}$ & $-0.96 \mathrm{NS}$ \\
\hline & 120 & $19.21 *$ & $-21.00 * *$ \\
\hline & 150 & $37.63 *$ & $4.06 \mathrm{NS}$ \\
\hline & 180 & $41.81 * *$ & $-7.13 \mathrm{NS}$ \\
\hline \multirow[t]{8}{*}{ E. cloeziana } & 30 & $0.81 \mathrm{NS}$ & $-11.73 \mathrm{NS}$ \\
\hline & 45 & $-20.32 * *$ & $-2.95 \mathrm{NS}$ \\
\hline & 60 & $-17.94 *$ & $-20.39 \mathrm{NS}$ \\
\hline & 75 & $24.91 * *$ & $10.76 \mathrm{NS}$ \\
\hline & 90 & 17.22 NS & $2.36 \mathrm{NS}$ \\
\hline & 120 & $37.06 * *$ & $-16.53 \mathrm{NS}$ \\
\hline & 150 & $27.90 * *$ & $-9.65 \mathrm{NS}$ \\
\hline & 180 & $50.09 * *$ & $-3.10 \mathrm{NS}$ \\
\hline \multirow[t]{8}{*}{ E. citriodora } & 30 & $-2.53 \mathrm{NS}$ & $12.55 \mathrm{NS}$ \\
\hline & 45 & $-20.35 *$ & $24.08 *$ \\
\hline & 60 & $-20.15 *$ & $-6.86 \mathrm{NS}$ \\
\hline & 75 & $13.41 \mathrm{NS}$ & $-5.63 \mathrm{NS}$ \\
\hline & 90 & $2.45 \mathrm{NS}$ & $-10.83 \mathrm{NS}$ \\
\hline & 120 & $18.24^{*}$ & $8.87 \mathrm{NS}$ \\
\hline & 150 & $51.92 * *$ & $-25.05 *$ \\
\hline & 180 & $53.81 * *$ & $-33.17 * *$ \\
\hline \multirow[t]{8}{*}{ E. urophyla } & 30 & - 7.01 NS & $-4.48 \mathrm{NS}$ \\
\hline & 45 & $-6.68 \mathrm{NS}$ & $0.40 \mathrm{NS}$ \\
\hline & 60 & $-12.57 \mathrm{NS}$ & $5.20 \mathrm{NS}$ \\
\hline & 75 & $6.61 \mathrm{NS}$ & $15.12 \mathrm{NS}$ \\
\hline & 90 & $28.30 * *$ & $-0.26 \mathrm{NS}$ \\
\hline & 120 & $29.90 * *$ & $-18.72 \mathrm{NS}$ \\
\hline & 150 & $42.95 * *$ & $3.24 \mathrm{NS}$ \\
\hline & 180 & $66.88 * *$ & $-15.58 \mathrm{NS}$ \\
\hline
\end{tabular}

$* * \mathrm{P}<0.01, * \mathrm{P}<0.05$ and NS not-significant by the $\mathrm{F}$ test at $5 \%$ of probability; ${ }^{1} \mathrm{C} 1=(\mathrm{AM}-\mathrm{T} 1)$ vs $(\mathrm{AM}-\mathrm{T} 3)$; this contrast compares the percentage of colonization by the AM fungus when individually inoculated versus the percentage of colonization by the AM fungus in the treatment of simultaneous inoculation with the ectomycorrhizal fungus; ${ }^{2} \mathrm{C} 2=(\mathrm{ECM}-\mathrm{T} 2)$ vs $(\mathrm{ECM}-\mathrm{T} 3)$; this contrast compares the percentage of colonization by the ectomycorrhizal fungus when individually inoculated versus the percentage of colonization by the ectomycorrhizal fungus in the treatment of the simultaneous inoculation with the ectomycorrhizal fungus.

\section{RESUMO}

\section{Sucessão de micorrizas vesicular-arbuscular e ectomicorrizas em mudas de Eucalyptus spp.}

A ocorrência de micorrizas arbusculares (AM) e ectomicorrizas (ECM) no mesmo sistema radicular foi observada quando Eucalyptus urophylla S.T. Blake, E. citriodora Hook F., E. grandis W. Hill ex Maiden, E. cloeziana F. Muell e E. camaldulensis Dehnh foram inoculadas simultaneamente com Glomus etunicatum Becker \& Gederman and Pisolithus tinctorius (Per.) Cocker \& Couch. A sucessão entre os dois fungos foi observada. De modo geral, o aumento da colonização ECM foi acompanhado de um decréscimo em AM. A inoculação simultânea resultou em percentagens de colonização diferenciadas das obtidas com a inoculação isolada. Pisolithus tinctorius beneficiou-se da inoculação simultânea com $G$. etunicatum. Para o fungo AM, o efeito positivo da inoculação simultânea ocorreu até aos 60 dias após a inoculação. A partir de 120 dias, a colonização das raízes por G. etunicatum diminuiu na presença de $P$. tinctorius. A proporção de AM e ECM variou com o tempo de avaliação e o total da percentagem de raízes colonizadas aproximou-se do valor máximo aos 60 dias da inoculação, mantendo-se constante. Os maiores valores foram observados para E. camaldulensis, seguido por E. citriodora, E. urophylla, E. grandis e E. cloeziana.

Palavras-chave: Glomus etunicatum, Pisolithus tinctorius, sucessão, Eucalyptus

\section{REFERENCES}

1. Amorim, E.F.C. Comportamento de mudas de Eucalyptus grandis na presença de fungos endo e ectomicorrízicos. Viçosa, Minas Gerais, 1988, 56p. (M.S. Thesis. Universidade Federal de Viçosa. UFV).

2. Baylis, G.T.S. Endogonaceous mycorrhizas synthesized in Leptospermum (Myrtaceae). N. Z. J. Bot., 9:293-296, 1971.

3. Bellei, M.M.; Garbaye, J.; Gil, M. Mycorrhyzal succession in young Eucalyptus viminalis plantations in Santa Catarina (southern Brazil). For. Ecol. Manage., 54: 205-213, 1992.

4. Boudarga, K.; Lapeyrie, F.; Dexheimer, J. A technique for dual vesiculararbuscular endomycorhizae/ectomycorhizal infection of Eucalyptus in vitro. New Phytol., 114:73-76, 1990.

5. Buwalda, J.G.; Ross, G.J.S.; Stribley, D.P.; Tinker, P.B. The development of endo-mycorrhizal root systems III. The mathematical representation of the spread of vesicular-arbuscular mycorrhizal infection in root systems. New Phytol., 91:669-682, 1982a.

6. Buwalda, J.G.; Ross, G.J.S.; Stribley, D.P.; Tinker, P.B. The development of endomycorrhizal root systens. IV. The mathematical analysis of effects of phosphorus on the spread of vesicular-arbuscular mycorrhizal infection in root systems. New Phytol., 92:391-399, $1982 b$.

7. Buwalda, J.G.; Stribley, D.P.; Tinker, P.B. The development of endomycorrhizal root systems. V. The detailed pattern of infection and the control of development of infection level by host in young leek plants. New Phytol., 96:411-427, 1984.

8. Carling, D.E.; Brown, M.F.; Brown, R.A. Colonization rates and growth responses of soybean plants infected by vesicular-arbuscular fungi. Can J Bot., 57:1769-1772, 1979. 
9. Chilvers, G.A.; Gust, .LW. The development of mycorrhizal populations on pot-grown seedlings of Eucalyptus st-johnii R. T. Bak. New Phytol., 9:677-699, 1982.

10. Chilvers, G.A.; Lapeyrie, F.F.; Horan, D.P. Ectomycorrhizal vs endomycorrhizal fungi within the same root system. New Phytol., 107:441-448, 1987.

11. Comerlato, A.G. Especificidade e eficiência de fungos ectomicorrízicos para Eucalyptus. Viçosa, Minas Gerais, 1992, 57p. (M.S. Thesis. Universidade Federal de Viçosa. UFV).

12. Dighton, J.; Mason; P.A. Mycorrhizal dynamics during forest tree development. In: Moore, D.; Casselton, L.A.; Wood, D.A.; Frankland, C.J. (eds). Developmental biology of higher fungi. Cambridge Univ, Press, Cambridge, 1985, p.117-139.

13. Dominik, T. Mycotrophy of poplars in their natural associations in Poland. Pol. For. Ann., 14:247-266, 1956.

14. Duchesne, L.C.; Peterson, R.L.; Ellis, B.E. Pine root exudate stimulates the synthesis of antifungal compounds by the ectomycorrhizal fungus Paxillus involutus. New Phytol., 108:471-476, 1988.

15. Giovannetti, M.; Mosse, B. An evaluation of techniques for measuring vesicular-arbuscular mycorrhizal infection in roots. New Phytol., 84:489-500, 1980.

16. Hepper, $\mathrm{CH}$. Influence of age of roots on the pathern of vesiculararbuscular mycorrhizal infection in leek and clover. New Phytol. 101:685-693, 1985.

17. Jakobsen, J.; Nielsen, N.E. Vesicular-arbuscular mycorrhizae in field grown crops. I. Mycorrhizal infection in cereals and peas at various times and soils depths. New Phytol., 93:401-413, 1983.

18. Koske, R.E.; Gemma, J.N. A modified procedure for staining roots to detect V.A. mycorrhizas. Mycol. Res., 92:486-505, 1989.

19. Lapeyrie, F.F.; Chilvers, G.A. An endomycorrhiza - ectomycorrhiza succession associated with enhanced growth of Eucalyptus dumosa seedlings planted in a calcareous soil. New Phytol., 100:93-104, 1985.
20. Last, F.T.; Mason, P.A.; Wilson, J.; Deacon, J.W. Fine roots and sheating mycorrhizas: their formation, function and dynamics. Plant Soil, 71:9-21, 1983.

21. Last, F.T.; Dighton, J.; Mason, P.A. Successions of sheating mycorrhizal fungi. Trends Ecol. Evol., 2:157-160, 1987.

22. Lodge, D.J.; Wentworth, T.R. Negative associations among VA mycorrhizal fungi and some ectomycorrhizal fungi inhabiting the same root system. OIKOS, 57:347-356, 1990.

23. Marx, D.H. The influence of ectotrophic mycorrhizal fungi on the resistance of pine roots to pathogenic infection. I. Antagonism of mycorrhizal fungi to root pathogenic fungi and soil bacteria. Phytopathol., 59:153-163, 1969.

24. Marx, D.H.; Davey, C.B. The influence of ectotrophic mycorrhizal fungi on resistance of pine roots to pathogenic infections. III. Resistance of aseptically formed mycorrhizae to infection by Phytophthora cinanamoni. Phytopathol., 59:549-558, 1969.

25. Mejstrik, V.K.; Cudlin, P. Mycorrhiza in some plant desert species in Algeria. Plant Soil, 71:363-366, 1983.

26. Mosse, B.; Stribley, D.P.; LeTacon, F. Ecology of mycorrhizae and mycorrhizal fungi. Adv. Microb. Ecol., 5:137-210, 1981.

27. Phillips, J.M.; Hayman, D.S. Improved procedures for clearing roots and staining parasitic and vesicular-arbuscular mycorrhizal fungi for rapid assessment of infection. Trans. Brit. Mycol. Soc., 55:158-161, 1970.

28. Smith, S.E.; Walker, N.A. A quantitative study of mycorrhizal infection in Trifolium: separate determination of the rates of infection and of mycelial growth. New Phytol., 89:225-240, 1981.

29. Sward, R.J. Infection of Australian heathland plants by Gigaspora margarita (a vesicular-arbuscular mycorrhizal fungus). Aust. J. Bot., 26:253-264, 1978.

30. Warner, A.; Mosse, B. Factors affecting the spread of vesiculararbuscular mycorrhizal fungi in soil. I. Root density. New Phytol., 90:529-536, 1982.

31. Zak, B. Role of mycorrhizae in root disease. Ann. Rev. Phytopathol., 2:377-392, 1964 . 